\title{
Accumulation of Proline in NaCl-treated Callus of Six Tomato (Lycopersicon esculentum Mill.) Cultivars
}

\author{
A.N. Mohamed, M.H. Rahman, A.A. Alsadon and R. Islam* \\ Department of Plant Production, College of Food and Agricultural Sciences, King Saud \\ University, P.O. Box No. 2460, Riyadh 11451, Saudi Arabia \\ Key words: Lycopersicon escutentum, Callus, Proline
}

The synthesis, accumulation and degradation of proline are highly regulated by environmental stresses such as salt, drought and metals. This phenomenon has been documented in many plants (Aspinall and Paleg 1981, Kavi-Kishor et al. 2005). In response to stress conditions plants increase osmotic potential within their cells by synthesizing and accumulating compatible osmolytes. Proline is considered one of the most common compatible osmolytes (Claussen 2005) which is directly involved with the osmotic adjustment of the plant cell to external salt stress (Rhodes et al. 1986, Rhodes and Handa 1989). The accumulation of free proline has been studied in a number of taxa subjected to hyperosmotic stress conditions for over 45 years. The accumulation of proline under environmental stress conditions depends on the plant species and the stress level (Kavi-Kishor et al. 2005). Proline seems to have diverse roles under osmotic stress, such as stabilization of protein structures against denaturation; it also stabilizes cell membranes by interacting with phospholipids, and subcellular structures thereby protecting cellular functions (Aspinall and Paleg 1981, Samaras et al. 1995, Kavi-Kishor et al. 2005)

Soil salinity is a major constraint in limiting plant growth. Although proline is known to confer osmotic tolerance during stress conditions, its specific role during plant growth is not completely known (Kavi-Kishor et al. 2005).

In some Solanaceae family like potato, proline plays a vital role in osmotic adjustments (Bussis and Heineke 1998). In tobacco cells this response seems to be related to their salt tolerance since proline content is higher in salt adapted cells (Rhodes and Handa 1989). Preliminary experiments showed that tomato plants subjected to salt stress conditions accumulated relatively high amount of proline (Hernandez et al. 2000). There is a positive correlation in proline accumulationin reported in tomato callus under salt stress (Tal et al. 1978).

*Department of Botany, University of Rajshahi, Rajshahi-6205, Bangladesh.

E-mail: rislamakm@yahoo.com 
The plant tissue culture approach has proven effective for obtaining salt tolerant plants (Patnaik and Debata 1997b; Purohit et al. 1998) and for quick evaluation of germplasm against salt stress. This technique has also proved useful in the study of salt tolerance mechanisms and the identification of specific cellular pathways involved in proline biosynthesis during stress conditions (Dutta-Gupta et al. 1995, Patnaik and Debata 1997a, Claussen 2005, Kavi-Kishor et al. 2005).

The calli of six tomato (Lycopersicon esculentum Mill.) cultivars raised from hypocotyl explants were tested with five levels $(0,25,50,75$ and $100 \mathrm{mM})$ of $\mathrm{NaCl}$ and their effects on proline accumulation were examined. The cultivars used in the present experiment were Pascal, Imperial, Queen, Tnshet crystal, Tnshet star and Pahuja.

Seeds of the tomato cultivars were surface sterilized by $8 \%$ Clorox for 10 minitues and rinsed four times with sterile distilled water. Seed germination was carried out in vitro with MS under complete darkness in growth chamber (digitally controlled) with $80 \%$ relative humidity at $25^{\circ} \mathrm{C}$ for one week. The hypocotyl segments were cut $(10 \mathrm{~mm})$ from germinated seeds and cultured on MS supplemented with $2.26 \mu \mathrm{M} 2,4-\mathrm{D}$ and $2.32 \mu \mathrm{M} \mathrm{Kn}$ for callus initiation. The media were solidified with agar (Difco-Bacto, $7 \mathrm{~g} / \mathrm{l}$ ) and added $30 \mathrm{~g} / 1$ sucrose and the $\mathrm{pH}$ was adjusted to 5.7. The calli were incubated with $14 \mathrm{~h}$ photoperiod and a light intensity of $6.26 \mu \mathrm{mol} \mathrm{m}^{-2} \mathrm{~s}^{-1}$ (white fluorescent tubes) at $25 \pm 1^{\circ} \mathrm{C}$ for one month. Subsequently the proliferating calli were transferred to same medium with different levels of $\mathrm{NaCl}(0,25,50,75$ and $100 \mathrm{mM})$. The $\mathrm{NaCl}$ treated calli were grown under the same photoperiod and temperature regime for one month. Fresh calli obtained from $\mathrm{NaCl}$ treatments were harvested and proline was measured according to the method of Bates et al. (1973). The $400 \mathrm{mg}$ fresh weight of callus samples were used for extraction and estimation of proline. The samples were homogenized in $10 \mathrm{ml}$ of $3 \%(\mathrm{w} / \mathrm{v})$ aqueous sulphosalicylic acid and the homogenate was filtered through filter paper (Whatman No. 1). In a test tube $2 \mathrm{ml}$ of the filtrate was mixed with $2 \mathrm{ml}$ acid ninhydrin and $2 \mathrm{ml}$ glacial acetic acid and incubated in $100^{\circ} \mathrm{C}$ water bath for $1 \mathrm{~h}$. The reaction mixture was terminated by placing in ice bath, extracted with $4 \mathrm{ml}$ toluene and the chromophore phase was aspirated from the aqueous phase. The absorbance was read at $520 \mathrm{mM}$ using spectrophotometer.

The experiment was designed as completely randomized and with four replications. Data were subjected to analysis of variance and the means were separated using LSD at $5 \%$. To confirm results the experiment was repeated twice.

The callus on medium having $\mathrm{NaCI}$ showed cream in colour and no necrotic patches were found in callus during tile culture period. The $\mathrm{NaCl}$ treated calli 
exhibited higher levels of proline than that of non-treated $(\mathrm{NaCl}$ free) counterpart. Highest amount of proline accumulated in callus of Pahuja derived from $100 \mathrm{mM} \mathrm{NaCI}$ medium, while the lowest was noted in Imperial in $\mathrm{NaCl}$ free medium (Table 1). Callus produced the highest amount of proline with a content of $7.09 \mathrm{mg} / \mathrm{g}$ fresh weight in Pahuja; i.e. values two times higher than those of Pascal and Tnshet Crystal treated with $100 \mathrm{mM} \mathrm{NaCl}$ added to the medium.

Table 1. Proline accumulation of $\mathrm{NaCI}$ treated callus derived from hypocotyl explants of six tomato cultivars.

\begin{tabular}{lccccc}
\hline & \multicolumn{5}{c}{ Proline accumulation $(\mathrm{mg} / \mathrm{g}$ fresh weight $)$} \\
\cline { 2 - 6 } Cultivars & 0 & 25 & 50 & 75 & 100 \\
\cline { 2 - 6 } & $0.20 \pm 0.05 \mathrm{c}$ & $0.40 \pm 0.10 \mathrm{c}$ & $0.36 \pm 0.12 \mathrm{c}$ & $1.29 \pm 0.39 \mathrm{~b}$ & $3.13 \pm 0.71 \mathrm{a}$ \\
Pascal & $0.10 \pm 0.01 \mathrm{c}$ & $0.22 \pm 0.06 \mathrm{c}$ & $0.58 \pm 0.15 \mathrm{c}$ & $0.81 \pm 0.37 \mathrm{~b}$ & $4.00 \pm 1.26 \mathrm{a}$ \\
Imperial & $0.19 \pm 0.01 \mathrm{e}$ & $0.43 \pm 0.08 \mathrm{c}$ & $0.90 \pm 0.19 \mathrm{c}$ & $2.37 \pm 0.91 \mathrm{~b}$ & $3.59 \pm 0.79 \mathrm{a}$ \\
Queen & $0.16 \pm 0.02 \mathrm{c}$ & $0.26 \pm 0.05 \mathrm{c}$ & $0.32 \pm 0.05 \mathrm{c}$ & $0.90 \pm 0.13 \mathrm{~b}$ & $2.31 \pm 0.38 \mathrm{a}$ \\
Tnshet Crystal & $0.26 \pm 0.05 \mathrm{c}$ & $0.27 \pm 0.07 \mathrm{c}$ & $0.74 \pm 0.13 \mathrm{c}$ & $1.47 \pm 0.52 \mathrm{~b}$ & $4.36 \pm 1.29 \mathrm{a}$ \\
Tnshet star & $0.24 \pm 0.04 \mathrm{c}$ & $0.34 \pm 0.09 \mathrm{c}$ & $1.58 \pm 0.65 \mathrm{c}$ & $2.95 \pm 0.82 \mathrm{~b}$ & $7.09 \pm 1.35 \mathrm{a}$ \\
\hline
\end{tabular}

Values shown are means of four replicates \pm SE. In the column, values followed by same letters are not significantly different according to DMRT at $\mathrm{p}=0.05$.

The proline accumulation was not significantly different on medium from 0 to $50 \mathrm{mM} \mathrm{NaCI}$ while those on higher range $(75-100 \mathrm{mM} \mathrm{NaCl})$ it was significantly different (Table 1). Callus obtained from Pahuja was more efficient to proline accumulation than other cultivars at $50-100 \mathrm{mM} \mathrm{NaCl}$. In response to $\mathrm{NaCl}$ treatments Pahuja, Queen and Tnshet crystal were found significantly different among other one, while Pascal, Imperial and Tnshet star showed moderate response in proline accumulation.

The results indicated that all tomato cultivars tested were able to accumulate proline under in vitro salinity stress. The rates of accumulation were different depending on cultivars and $\mathrm{NaCl}$ levels. Proline content increased significantly with an increase $\mathrm{NaCl}$ concentrations. The results are in agreement with Emilio et al. (1998) for Lycopersicon esculentum and L. pennellii. Using the same methods Martinez et al. (1996) found a positive relationship between proline accumulation and $\mathrm{NaCl}$ tolerance in potato.

\section{References}

Aspinall D and Paleg LG (1981) Proline accumulation: Physiological aspects. In: The Physiology and Biochemistry of Drought Resistance in Plants, Academic Press, Paleg 
LG, Aspinall D (Eds.), Sydney, pp. 205-241.

Bates LS, Watdren RP and Teare ID (1973) Rapid determination of free proline for water stress studies. Plant Soil 39: 205- 207.

Bussis D and Heineke D (1998) Acclimatization of potato plants to polyethylene glycol induced water deficit.II. Contents and subcellular distribution of organic solutes. J Exp. Bot. 49 : 1361-1370.

Claussen W (2005) Proline as a measure of stress in tomato plants. Plant Sci. 168: 241-248.

Dutta-Gupta S, Auge RM, Denchev PD and Conger BV (1995) Growth proline accumulation and water relations of NaCI-selected and non-selected callus lines of Dactylis glomerata L. Environ. Exp. Bot. 35: 83-92 .

Emilio AC, Francisco PA, Vicente M, Manuel C and Maria CB (1998) Evaluation of salt tolerance in cultivated and wild tomato species through in vitro shoot apex culture. Plant Cell, Tiss Org. Cult. 53: 19-26.

Hernandez S, Deleu C and Larher F (2000) Proline accumulation by leaf tissues of tomato plants in response to salinity. Life Sciences 323: 551-557.

Kavi-Kishor PB, Sangam S, Amrutha RN, Sri-Laxmi P, Naidu KR, Rao KRSS, Rao S, Reddy KJ, Theriappan $\mathbf{P}$ and Sreenivasulu N (2005) Regulation of proline biosynthesis, degradation, uptake and transport in higher plants: Its implications in plant growth and abiotic stress tolerance. Curl. Sci. 88: 3.

Martinez CA, Maestri M and Lani EG (1996) In vitro salt tolerance and proline accumulation in Andean potato (Solanum spp.) differing in frost resistance. Plant Sci. 116: $177-184$.

Patnaik J and Debata BK (1997a) In vitro selection of NaCI tolerant callus lines of Cymbopogon martini (Roxb.). Plant. Sci. 124: 203-210.

Patnaik J and Debata BK (1997b) Regeneration of plantlets from NaCI tolerant callus lines of Cymbopogon martini (Roxb.). Plant Sci. 128: 67-74.

Purohit M, Srivastava S and Srivastava PS (1998) Stress tolerant plants through tissue culture. In: Plant tissue culture and molecular biology: Application and prospects. Srivastava PS (Ed), New Delhi, Narosa Publishing House, pp. 554-578.

Rhodes D and Handa S (1989) Amino acid metabolism in relation to osmotic adjustment in plant cells. In: Biochemical and physiological mechanisms associated with environmental stress tolerance. Cherry JH (Ed), Springer-Verlag, Berlin, pp. 41-62.

Rhodes D, Handa S and Bressan RA (1986) Metabolic changes associated with adaptation of plant cells to water stress. Physiol. Plant. 82: 890-903.

Samaras Y, Bressan RA and Csonka LN, Garcia-Rios MG, Paino D, Urzo M and Rhodes D (1995) Proline accumulation during drought and salinity. In: Environment and plant metabolism, Smirnoff N (Ed), Bio Scientific Publishers, Oxford, pp. 161-187.

Tal M, Heikin H and Dehan K (1978) Salt tolerance in the wild relatives of the cultivated tomato: responses of callus tissues of Lycopersicon esculentum, L peruvianum and Solanum pennellii to high salinity. J. Pflanzenphysiol. 86: 231-240. 